\title{
Organizational and Epistemic Change: The Growth of the Art Investment Industry
}

\author{
Erica Coslor \\ University of Melbourne, Department of Management and Marketing \\ Victoria, Australia 3010 \\ ecoslor@unimelb.edu.au \\ Christophe Spaenjers \\ HEC Paris, Department of Finance \\ 78351 Jouy-en-Josas, France \\ spaenjers@hec.fr
}

AOM PAPER

\begin{abstract}
This case shows how an emergent knowledge community is necessary to support and legitimate the efforts of entrepreneurs in new areas of financial investment, due to strong, institutionalized expectations about the rational evaluation and monitoring of financial assets. Using the concept of epistemic cultures to complement an organizational field narrative, this paper examines the development of artwork as a recognizable financial investment category. Despite a long history of attention to art investment, the legitimacy of art as an asset is still emerging. Legitimacy questions have decreased since the 1960s due to the growth of an epistemic culture around art investing, facilitated by new market actors who met the need of professional investors for transparency and accountability. Technical knowledge about art investments came from economists, art price service providers, art market analysts, and others. We also see the development of a more practical knowledge about how best to structure the investment and to profit from art investment. The growth of knowledge through a series of experiments and failures - around the properties and optimal structure of art investments was just as important for the emergence of the industry as having investors who were willing to enter the new area.
\end{abstract}

Keywords: new market creation; legitimacy; epistemic cultures; institutionalized expectations; investment management; art market. 
The process of industry change and new market creation has been an ongoing area of interest for organization studies, and market niches often arise at the nexus of two previously separate markets. In such cases, an important question is how existing institutions interact with new markets and products. This is especially true because the development of new industries is not necessarily a simple and straightforward process: there can be experiments and failures as a new market area develops. We argue that the science studies theory of epistemic cultures can help us viewing such short-term twists and turns, which occur within a more slowly changing institutional infrastructure, as a necessary part of the entrepreneurial and fielddevelopment process.

This paper examines the development of a new market area that grew out of the boundary between two quite different markets, the fine art market and the professional financial investment market, and the difficulties that prevented the rapid establishment of this market. We describe what we might call a financialization project, a promotional and entrepreneurial effort that was essential in establishing the art market as an investment niche. This project encompassed tendencies toward institutional isomorphism, to recreate existing structures in financial investment (Velthuis \& Coslor, 2012), and the growth of epistemic knowledge (Knorr Cetina, 1999) around the properties of art as an investment.

Our paper does not argue that art investment is a good or bad idea. Quite the opposite: the documented efforts are especially interesting for organization studies because of the paradoxical nature of art investment: even though high-profit stories abound in the popular press, art does not necessarily provide high financial returns on average (Baumol, 1986; Frey \& Eichenberger, 1995; Pesando, 1993; Renneboog \& Spaenjers, 2012 forthcoming). We use a mixed-methods approach to examine the emergence of the art investment industry. In a first study, we build upon a database of English-language books to examine the trajectory of the usage of art investment lexicon (e.g., "art market”, “art auction”) over the twentieth 
century. We find a strong increase in the use of art investment language as of the late 1960s. This trend cannot simply be explained by growing attention paid to art or collectibles more generally. Building on this finding, in a second study, we provide a more nuanced historical account that traces the growth of the art investment industry over the last half century, highlighting the epistemic (knowledge-based) and organizational field-level developments. The key innovation that undergirded the epistemic culture was the development of art price indexes, tools that enabled benchmarking and analysis and were refined by academic economists as well as new industry entrants, such as art price providers and art market analysts.

This case highlights the complementary nature of the organizational and epistemic developments in establishing industry legitimacy and investment recognizability. This financialization effort included the entry of new actors, a field level change, but the fieldlevel explanation is inadequate without developments at both the epistemic level, in terms of knowledge about art, and at the organizational level, in terms of how best to structure the investment.

\section{Institutions as Durable Constraints on Market Activity}

We would like to highlight institutions as developed and durable forces that set the scope for whether a given asset category can be recognized as a legitimate investment. Institutionalized expectations shape organizational forms and market strategies (Friedland \& Alford, 1991; Zuckerman, 1999), by constraining organizational and individual practices and assumptions within prevailing institutional logics (Thornton \& Ocasio, 2008). According to Zuckerman, “organizations that do not meet institutionalized expectations for how they should look and act are viewed as illegitimate,” creating pressure to conform to accepted procedures (Zuckerman, 1999). This theory posits legitimacy rather than efficiency for explaining organizational survival (Thornton \& Ocasio, 2008; Tolbert \& Zucker, 1983), and would 
imply that new investment areas must 'look right': they must be recognizable in order to be seen as legitimate (Star \& Griesemer, 1989). These pressures and expectations are clearly evident in the case at hand, where financial market actors have a strong and well-established set of taken-for-granted assumptions. These assumptions interrelate with criteria about actual market performance in interesting ways. Market performance clearly continues as a constraint, but money-making schemes without an underlying theoretical basis may be deemed illegitimate (Lounsbury \& Crumley, 2007). As Carruthers and Stinchcombe point out, the liquidity of a market depends upon the 'know-ability' of the commodity that is being transacted; "an asset with transparent economic value, whose features can be credibly communicated to a large enough audience (...) can be 'taken for granted'” (1999).

\section{Epistemic Cultures in Context of Institutional Theory}

We present a way of understanding innovations, experiments, and tests that occur within a more slowly changing institutional infrastructure, achieved through the science studies theory of epistemic cultures. Epistemic cultures encompass the practices, tools and assumptions that help to constitute expert cultures, particularly knowledge and technology dominant fields (Knorr Cetina, 1999). They are “amalgams of arrangements and mechanisms” that make up "how we know what we know" (Knorr Cetina, 1999). A key example is that of a scientific field, but it could also be an industry that requires strong technical expertise.

Although at first glance this would seem to replicate the theory of institutional logics and norms (e.g. DiMaggio, 1988), the theory is distinct because epistemic cultures typically include an evaluation culture (MacKenzie, 2011) and focus on technical devices (Callon, 1987; Munesia, Millo, \& Callon, 2007). The inclusion of tools and evaluation makes the epistemic cultures viewpoint on the development of expert knowledge in a new industry particularly helpful when studying products that are rationally evaluated before purchase. The concept is thus useful in understanding the creation and packaging of new financial 
investment areas that must meet durable expectations, because the ability to understand and quantify potential returns is often directly related to the market for, and success of, these products. This is a similar line of thinking to Lounsbury and Crumley’s study (Lounsbury \& Crumley, 2007) of the mutual fund industry, where a new theoretical basis is necessary to support new forms of money management. However, we provide several understandings that can help to explain the changing practices in the context of durable institutions.

\section{Experiments and Evolving Objects}

Epistemic cultures are necessarily evolving and changing, giving a different starting point than more durable institutional arrangements. They encompass a native concept of experimentation, given the focus on scientific research. The idea of experimentation is especially useful when we think about financial products, because we do not necessarily know what will end up being a good investment strategy. It can lead to an increasing variety of products and strategies, as pointed out by Lounsbury and Crumley in their example of money management practices (2007). Moreover, with the strong need for benchmarking and measures in investing, we must also experiment with measures. In some areas of science, measurements "count as evidence... considered capable of proving or disproving theories, of suggesting new phenomena, of representing... 'results,'” even if these measurements are theory-laden or potentially subject to re-interpretation (Knorr Cetina, 1999).

Experimentation is useful as a mental model to understand how drafts are produced, tests are conceived, trials are run, and concepts are refined. It also helps to highlight the faster-moving temporal dimension, nesting these experiments within durable institutional expectations like the interior of a set of Russian dolls. In the role of an exterior infrastructure, institutional logics are important in this case because they provide a way to understand the durable expectations about how potential investors and market participants recognize, evaluate, and compare financial investments. 


\section{RESEARCH CONTEXT: THE FINE ART MARKET}

In 2011, the turnover in the global art market was estimated at $\$ 60.8$ billion (McAndrew, 2012). The art market has grown substantially over the last couple of decades. McAndrew (2012) estimates that the total value of art sales has more than doubled between the market peak in 1990 (\$27.2 billion) and the next peak in 2007 (\$65.8 billion). The author also shows that, in terms of sales at Sotheby's and Christie’s, turnover grew at an average annual rate of 7\% and 9\% respectively between 1986 and 2011. Traditional financial markets clearly dwarf the art market. For example, the average daily turnover of global foreign exchange instruments was nearly \$1 trillion in late 2011 (New York Fed, 2012). That does not imply, however, that art is negligible in terms of asset values. About half of the wealthy individuals recently surveyed by Barclays (2012) have an art collection.

\section{STUDY 1: POPULAR ATTENTION TO ART INVESTMENT}

To examine long-term trends in the interest in art investment, we traced the use of art investment lexicon, a set of terms related to art investment, over the course of the twentieth century. Michel et al. (2011) created a corpus of over 500 billion words drawn from about five million books, mainly from university libraries, with digitization by Google. The authors estimated that they were able to capture approximately $4 \%$ of all books ever published. Their raw data, which is available online and underlies Google’s so-called "Ngram Viewer," allow for a computational analysis of the trends in the usage frequency of short sequences of words. Such variation can document linguistic change but also cultural change, i.e. changes "in the concepts we discuss” (Michel et al., 2011).

\section{Data and Methods}

Our starting point was an analysis of the usage frequency of 2-grams, i.e. sequences of two words, that were present in English-language books. We recognize that the study of an art 
investment lexicon from books, rather than newspaper and magazine articles, presents a potential limitation to the interpretation of our data. However, the advantage of this dataset is that it is internally consistent and ensures broad coverage in a way that might be of concern with selecting one or several newspapers or magazines to study for this research.

The 100 available text files, each containing many millions of lines, were downloaded from the Ngram Viewer website (Google, 2009). (The 2-gram files are not sorted alphabetically with respect to each other.) The data give for every 2-gram and for every year the total number of times the sequence occurred, and the number of distinct pages and books in which it appeared. For example, the 2-gram “art market” occurred 389 times on 321 distinct pages in 133 of the books published in 1982 that are included in the database, while "art investment(s)” occurred 16 times on 15 pages in 12 books in the same year.

We are interested in the trajectory of the use of the art investment lexicon over the twentieth century. Although there is also data available for the most recent years, "the corpus composition undergoes subtle changes around the time of the inception of the Google Books project." ${ }^{1}$ For each year between 1898 and 2002, we aggregated the number of distinct pages per year which include the lexical terms shown in Table 1. We also search for the capitalized equivalents of these 2-grams, since the data are case-sensitive.

Table 1: Art Investment Lexicon

\begin{tabular}{|c|c|c|c|c|c|}
\hline "art auction(s)" & "art buyer(s)” & “art buying” & $\begin{array}{l}\text { “art } \\
\text { dealer(s)” }\end{array}$ & “art fair(s)” & "art fund(s)" \\
\hline $\begin{array}{l}\text { "art } \\
\text { investment(s)" }\end{array}$ & $\begin{array}{l}\text { "art } \\
\text { investor(s)" }\end{array}$ & “art market(s)” & $\begin{array}{l}\text { "art } \\
\text { price(s)" }\end{array}$ & $\begin{array}{l}\text { "art } \\
\text { purchase(s)" }\end{array}$ & "art return(s)" \\
\hline “art sale(s)” & "art trade" & $\begin{array}{l}\text { “art } \\
\text { transaction(s)" }\end{array}$ & $\begin{array}{l}\text { "art } \\
\text { value(s)" }\end{array}$ & $\begin{array}{l}\text { "art } \\
\text { valuation(s)" }\end{array}$ & $\begin{array}{l}\text { “auction(ing) } \\
\text { art” }\end{array}$ \\
\hline "buy(ing) art" & $\begin{array}{l}\text { “deal(ing) } \\
\text { art” }\end{array}$ & $\begin{array}{l}\text { "purchase(/-ing) } \\
\text { art” }\end{array}$ & $\begin{array}{l}\text { "trade(/-ing) } \\
\text { art" }\end{array}$ & $\begin{array}{l}\text { "value(/-ing) } \\
\text { art” }\end{array}$ & \\
\hline
\end{tabular}

\footnotetext{
${ }^{1}$ http://www.culturomics.org/Resources/A-users-guide-to-culturomics. Sourced 11/1/2012.
} 
One potential concern with these data is that documented trends could mechanically follow from changes in the interest in art, or from changes in the coverage of art-related publications by Google Books. Hence, we scaled the aggregated counts by the usage frequency of the word "painting” in each year. (Scaling by "art” gives similar results.) To highlight the longerterm trends, we smoothed the resulting series by computing the five-year centered moving averages. Thus, the reported value for each year $T$ between 1900 and 2000 is the average of years $T-2$ to $T+2$. Finally, we rescaled the index such that the value in 1900 was equal to 100 .

\section{Results}

Figure 1 presents our results, with a clear upward trend in the use of the art investment lexicon between 1900 and 2000. Moreover, the graph shows a much higher rate of increase after the late 1960s than before. Additional analysis of the data showed that this is mainly due to the frequent occurrence of the terms "art market”, "art dealer(s)", "art fair(s)", and "art auction(s)” in the later periods of our time frame.

Figure 1. Use of Art Investment Lexicon

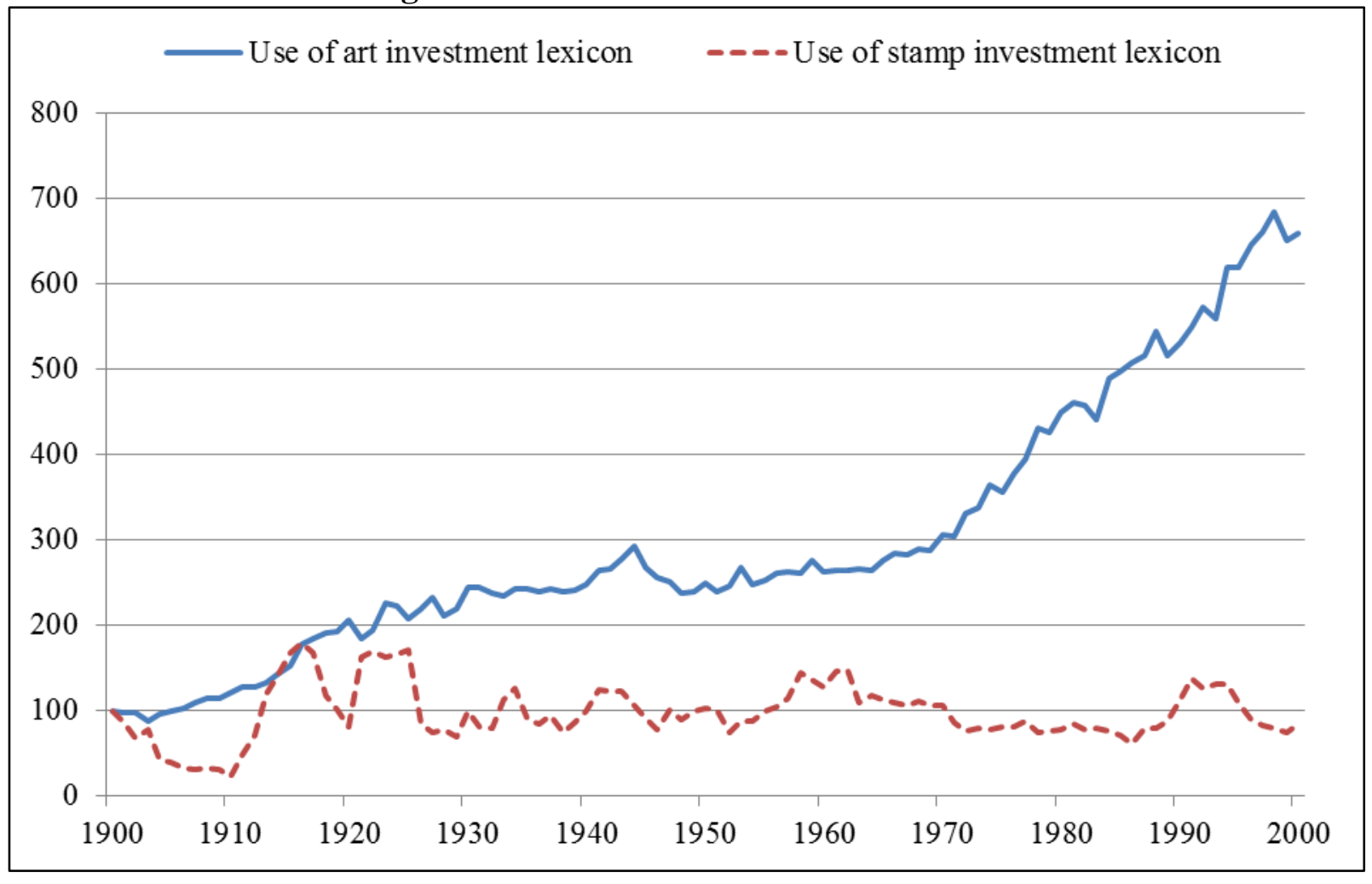




\section{Caveats and Alternative Interpretations}

One concern is that our results may be driven by a more general increase in the attention given to the pricing and trading of collectibles over time. Therefore, as an additional check, we repeated our analysis for another collectible category that has been around for a reasonably long time, namely stamps. We focused on the use of the 2-grams "stamp auction(s)”, "stamp catalogue(s)”, and “stamp dealer(s).” These results were scaled by the aggregated use of the term "philately(/-ic, /-ist(s))" in each year. (The use of many related terms is hindered by the long history of food, trading, and tax stamps, and the fact that postage stamps are everyday consumer goods.) In contrast to art collecting, philately "has historically been underpinned by a market-based model of investing and trading” (Dimson \& Spaenjers, 2011). Like art, this market has seen the frequent publication of catalogues with price information. But with a dominant model of market-based investing already in place, developments like the publication of books on stamp investments (Lake, 1970) and of stamp price indexes (Duthy, 1978) should have had much less influence on the stamp market. Figure 1 indeed shows that the usage frequency of stamp investment lexicon does not show a clear trend over the twentieth century, in contrast to the art investment vocabulary.

\section{Discussion}

The growth of the art investment lexicon, especially in contrast to the trend for stamps, helps to show that something unique is, indeed, occurring in the art market over time. There is an accelerating concern with art market and investment language that is not simply explained by growing attention paid to paintings, nor is it explained by increasing attention paid to collectibles in general. To look at what is happening, and to understand why art is not simply accepted as an investment from the 1960s or 1970s, we must look more closely at the history of the field. Perhaps it is the case that interest alone is not enough to sustain the innovation in 
financial products, which also require the ability to evaluate them and document trends using accepted financial tools.

\section{STUDY 2: QUALITATIVE ANALYSIS OF THE DEVELOPMENT OF THE FIELD}

In contrast to the sustained and growing interest in art as an investment evidenced by the previous study, a survey of the history of the art market yields paradoxical findings. On the one hand, there are a good number of well-known historical examples of profits being made from art. In the late 1800s, steel baron Henry Clay Frick noted that "some paintings were seen to increase sometimes a hundred, thousand fold more rapidly than the certificates of the best-managed joint stock companies” (Chancellor 2000). On the other hand, however, the view of art as a recognizable investment category is much more recent. "Thinking of art as an asset class, and art funds, that's pretty recent,” one of our interview subjects points out. “There has been academic writing about it since the 1970s. Economics professors have felt that it is a funky market. But only recently has it been a consumer product, where before it was an academic product...” (art price service interview 2007).

This suggests that modern investing is somehow assigning different criteria that have made art into a difficult investment, despite the longstanding growth in interest shown in Study 1. To this end, we will argue that the contemporary art investment project is differentiated from previous examples and the mixed view of collecting for both pleasure and profit by two factors: the investment fund structure and the strong reliance on benchmarks and measures. In short, art must become recognizable as an asset using the institutional logics of financial markets.

\section{Data and Methods}

Study 2 draws from a larger historical and ethnographic case study on the high end art market and use of artwork as a financial investment (self-identifying citation withheld). We are 
primarily focusing on the historical data here. Starting with the general research question of how it was the case that art could be used as a financial investment, we followed Marcus' (1995) multi-sited ethnography approach, combined with the technique of "following the object," often used in studies of scientific and technological innovation. These data were analyzed throughout the research using a modified strategy of grounded theory (Chamaz \& Mitchell, 2002; Glaser \& Strauss, 1965). Interviews and field notes were coded for themes, working toward theoretical saturation with an iterative technique (Eisenhardt, 1989; Eisenhardt \& Graebner, 2007; Glaser \& Strauss, 1965, 1967; Richards, 2005). Although this method can be limited in terms of generalizability, it helps to generate new theories.

\section{Findings: Stages of Change in the Art Investment Space}

For coherence, we have identified both organizational and epistemic changes since the 1960s, when there is a noticeably increased interest in the art market and art prices. We present the findings in a roughly chronological fashion, using a set of historical stages that are generally characterized by a similar pattern consisting of a period of interest, growth, flourishing, and eventual die-offs. The stages as presented draw from the work of Velthuis and Coslor (2012).

Table 2. Stages of Industry-Level Developments in the Financialization of Art

\begin{tabular}{llll}
\hline Stage & Dates & Developments & Examples \\
\hline 1 & 1960s & $\begin{array}{l}\text { Early interest by economists } \\
\text { Early price indexes }\end{array}$ & $\begin{array}{l}\text { Reitlinger } \\
\text { Times-Sotheby Index }\end{array}$ \\
2 & 1970s to 1980s & $\begin{array}{l}\text { Early institutional investment } \\
\text { interest in art } \\
\text { British Rail Pension } \\
\text { Fund }\end{array}$ & \\
& 1980s to early & $\begin{array}{l}\text { Academic research } \\
\text { Art price services and growth } \\
\text { in market analysis } \\
\text { Dedicated art funds } \\
\text { Private art banking services }\end{array}$ & Artnet; Sotheby Index \\
& & $\begin{array}{l}\text { Explosion of research } \\
\text { Art investment funds using the } \\
\text { private equity structure } \\
\text { Development of supporting } \\
\text { 1990s to present }\end{array}$ & The Fine Art Fund \\
& & $\begin{array}{l}\text { Fine Art Wealth } \\
\text { industries }\end{array}$ & Management \\
\hline
\end{tabular}




\section{Stage 1: Early Interest by Economists and Early Price Indexes (1960s)}

As noted previously, there had been a longstanding historical interest in art, but in the late 1950s and 1960s, the art market was booming. There are many categories of financial investments, with varying degrees of differences and similarities. But art is a bit more difficult to conceptualize as a financial asset for a couple of reasons: each art work is unique; art does not provide financial cashflows to its owner; artworks trade infrequently and outside exchanges; transaction costs in the art market are high; etc. Nonetheless, building on the growing interest in art as a financial investment, we witness an increased interest by historians and economists.

\subsection{Early Interest by Economists}

From the late 1950s, a handful of books started to address the economic history of the art market. For example, Rheims $(1959,1961)$ wrote a history of art collecting, while the dense works of Gerard Reitlinger (1961, 1963, 1970) contained a qualitative discussion of historical evolutions in the art market and detailed lists of art transactions since 1760. Other work explicitly focused on promoting art as a potential investment (ex. Rush, 1961). These early efforts were limited by the difficulties in collecting reliable, representative art price data. Socalled art price catalogs - books of prices - were present from at least the 1880s (Coslor, 2011a), but did not always lend themselves to a systematic analysis. Nonetheless, this early research helped to inform strategies of the early investors in the next stage, as illustrated by the use of Reitlinger's figures by the British Rail Pension Fund (Watson, 1992).

\subsection{Early Price Indexes}

The increasing attention to the art market and art as an investment was coupled to a search for measures and metrics. A key development here was the creation of art price indexes. In financial markets, an index is a statistical indicator that represents the value of a basket of assets that belong to the same market or industry; it frequently serves as a benchmark against 
which the financial performance of individual securities can be evaluated. When looked at over time, they show price movements and trends, particularly when the numbers are turned into graphs; both numerical and charts allow comparisons with other investments.

Rush and Rheims. As discussed in Coslor (2011b), there were early efforts toward aggregating art prices into a systematic fashion. Auctioneer Maurice Rheims presents early indexes in his book on the art market (1959). In 1961, we also saw the publication of Richard Rush’s popular book “Art as an Investment,” featuring a number of charts of his indexes for different types of art, including a direct comparison to stocks. This reinforced the idea that paintings and stocks could be directly compared as potential investments.

Figure 2: Comparison of Art to Stocks in Rush (1961: 385)

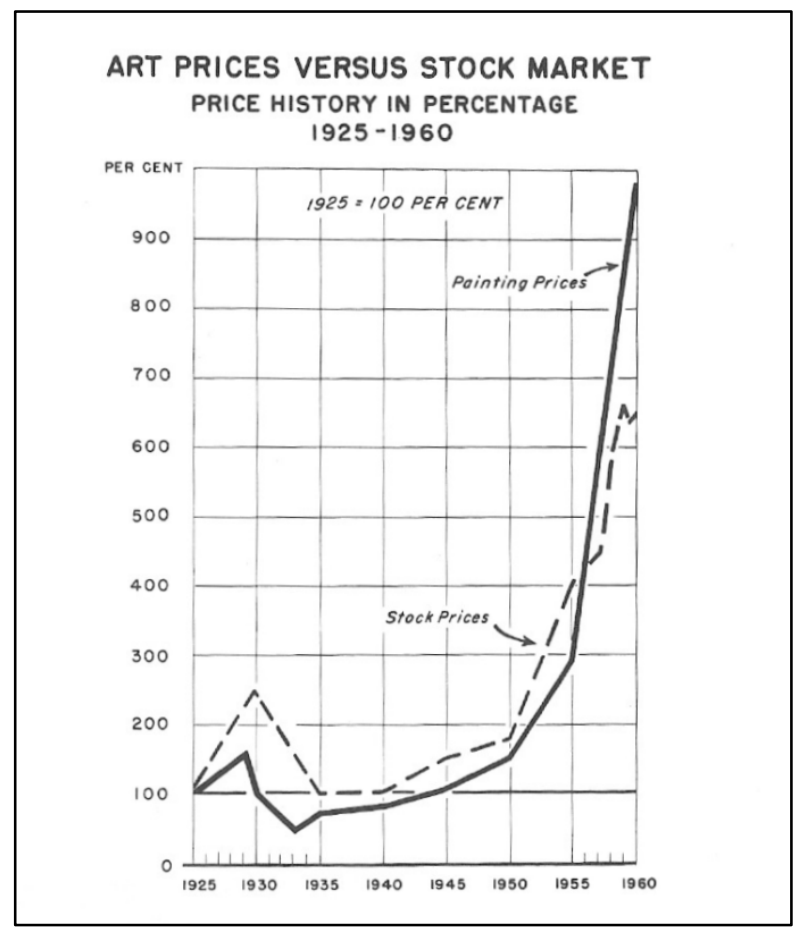

Times-Sotheby Index. Despite the popularity of Rush and Rheims, the most prominent index, however, was one that appeared on the pages of a newspaper. In 1967, London’s Sunday Times started running the Times-Sotheby price index. Put together by statistician Geraldine Keen, the index was the quantitative foundation for a charting of art prices. Using a representative basket of works, the index could, conveniently, be charted together with stocks 
and bonds. Critics of this effort have questioned whether the index itself was driving speculation (Hensher, 2006). More moderately, indexes such as the Times-Sotheby Index, allowed art investment to be made possible through the ability to compare art to stocks, bonds and other investments, both in theory, and by allowing the practical numerical calculation of time-series data that can represent the art market in a portfolio calculation (Coslor, 2011b).

\section{Stage 2: Early Institutional Investors and Growing Information Needs (1970s to 1980s)}

\subsection{Early Institutional Investors}

From the organizational perspective, the efforts toward financialization were driven by the entry of institutional investors in the art market, who were interested in the investment features of artwork and also faced different types of requirements that shaped their interest in art market data. An institutional investor is an entity such as an insurance company, investment company, or a trust department that invests large sums in the financial securities markets (Scott, 2003). The institutional investor interest in art is significant because these market entrants take the role of a pure investor in artwork, as opposed to individuals, who typically have mixed investment, consumption, status and other goals.

British Rail Pension Fund. The British Rail Pension Fund was the first large institutional investor to become involved in the art market, and was often mentioned during interviews with representatives from the art investment community. The goal was to match or beat inflation, which was difficult at the time, because, according to a former director of the Fund, “the stock market had fallen very heavily, the property market had collapsed... we didn’t have index linked securities. ...there weren't the options of commodities or hedge funds or international bonds,” and even with foreign investments, there were limitations, “and to diversify overseas, there were exchange controls and a high dollar premium...” (Adeane interview 2008). As one of the first, and perhaps only large British pension fund to enter the collectibles market at the time, the fund began buying art and antiques in 1974, in a 
partnership with Sotheby’s auction house (Cannon-Brookes, 1996). The collection eventually included more than 2,400 works of art of various types, such as paintings, books and manuscripts, medieval art and sculpture, and Chinese ceramics (Baram, 2005).

Other Art Funds. British Rail was pushed into this market by a lack of other viable investment opportunities, but they spurred a number of other followers. Key examples include Artemis, Modarco, and the Sovereign-American Arts Corporation (Horowitz, 2011). The influence of these funds was shown in art purchases, which could form a significant share in the art market. They also stimulated the growth of the epistemic community around art investment with money available for due diligence, art market research, and related efforts.

\subsection{Growing Information Needs}

Once British Rail became involved in the art market, there was a push to create tools, measures, models, and benchmarks to understand and quantify their involvement in the market. Eventually, to meet this need, a statistician, Jeremy Eckstein, was hired by Sotheby’s in 1979 to provide art market information about the investment, and was able to gain updated price estimates using the Sotheby's specialists. While he continued on at Sotheby's, Eckstein noted that even after his "responsibility towards the British Rail Fund wound down, there were always other clients who were interested [in art as an investment]. It wasn't just [that]; art as an investment led to a study of the economics of the art market, what made it work, looking at it in terms of supply and demand, the demographics of the buyers and sellers, and quantifying the returns and prices, so the initial interest in art as an investment spread more widely." ${ }^{2}$ Art also began to receive more scrutiny from academic financial economists around this time (e.g. Anderson, 1974; Stein, 1973). Moreover, the methodologies were applied to other areas of collectibles. For example, in the spirit of Rush’s “Art as an Investment,” (1961),

\footnotetext{
${ }^{2}$ Personal interview with Jeremy Eckstein, London, January 2009.
} 
Robin Duthy's books on alternative investments $(1978,1986)$ contained price indexes not only for art, but also for wine, stamps, and other categories.

There also came to be increasing links between academics and art price services. Duthy began the firm Art Market Research, which we will discuss more in later sections. Another effort was made by former finance professor Richard Rush, who in the 1970s was the editor of The Art Investment Report, which came up in various newspaper articles about art investing at that time. Readers of The Burlington Magazine (1973), an art-historical magazine, would have run across the following advertisement:

The Art Investment Report

An exciting, new bi-weekly newsletter for art collectors, dealers \& investors, edited by Richard H. Rush, author of 'Art as an Investment'. Gives you the vital facts you need to buy and sell art—profitably: market trends, tax questions, undervalued schools \& artists, selling at auctions, where to get best buys, etc. ${ }^{3}$

This new report leveraged the popularity of Rush’s 1961 book and highlighted a key concern - how to buy and sell art profitably, through trend analysis and other information. An undertone that we could interpret from this ad is that the report was targeting newcomers to the art market, who needed to learn how to properly buy and sell at auction.

\subsection{Portfolio Diversification Theories}

The collection of more data about the art market was important in its own right, but also because of the growing prioritization of portfolio diversification theory (Markowitz, 1952), which highlighted the importance of comovements between investment assets. Those interested in portfolio calculations needed a good basis for computation, usually found with an art price index. The idea of using art to lower overall investment risk was also present in the British Rail Pension Fund efforts, with the stated rationale that the decision to invest in art 
was based both on "further diversification of the overall portfolio" and on "reasonable prospects for long term capital appreciation, at least equal to inflation”. ${ }^{4}$

\subsection{Failures}

As the 1970s wore on, the supposed promise of art investment started to wane, and there was a die-off of funds, including the Sovereign-American Arts Corporation, the transition of Artemis into a publicly traded outfit, and merger of Modarco and Knoedler (Horowitz, 2011).

British Rail Pension Fund. Even British Rail, hailed as a successful example, decided to divest its holdings of artwork. Although the fund had been enjoying returns above $11 \%$, when the British press discovered that the fund was “gambling pensioners' money on artworks," the pension fund pulled the plug on its art investment activities (Baram, 2005). In addition to these types of moral concerns, the investment in art and antiques was also controversial at the time due to questions about whether the collection constituted trading or investment (Blake, 2003). The cancellation of the BRPF's venture into the art market helps to show that although individuals might be able to buy artwork for both aesthetics and profits, buying art and collectibles was still not a legitimate strategy for institutional investors.

Times-Sotheby Index. The Times-Sotheby Index was also cancelled, with rumors that it was due to the changed shape of the index-the auction house did not necessarily want to be associated with an index that did not show strong growth (see, e.g., Hayden-Guest, 1996).

\section{Stage 3: Intensification in Research and New Ventures and Funds (1980s to early 1990s)}

As one phase of interest in the art market ended, there was a series of die-offs and reorganizations. However, from the ashes we see a new stage, which relates to an intensification in research about art investment, and a number of new ventures.

\footnotetext{
${ }^{4}$ Railways Pension Fund - Investment in Works of Art. Susan Adeane, 02 October, 2003. (Company document.)
} 


\subsection{Art Market Research by Academics and Firms}

During this time, there was a growing area of work on the art market in cultural economics that used auction price data to study art price trends, mainly drawing from the dataset compiled by Reitlinger (e.g. Baumol, 1986; Frey \& Eichenberger, 1995; Goetzmann, 1993). This work provided quantitative ways to examine the potential financial profits from investing in art, particularly as compared to other types of financial assets like stocks and bonds, and we see the application of more advanced types of index construction methods. ${ }^{5}$ Academic Debates around Investment in Art. The academic debates during this time set up several types of conflicts. There were discussions of art investment as an arena where investors might be able to make major profits, contested by detractors, mostly in academic research, pointed out that transaction costs may make art a poor investment that yielded low returns, on average (Baumol, 1986; Frey \& Pommerehne, 1989). Following along the idea of portfolio diversification, others argued that because the returns could be variable, art could serve as an alternative investment or portfolio hedge. For example, Michael Bryan pointed out that art, as a durable commodity, helps to protect owners from unexpected inflation (Bryan, 1985), while Coffman (1991) suggested that there were still 'bargains' to be found, due to information lagging for art markets outside of the major centers.

Sotheby Index. The Times-Sotheby price index may have been cancelled in the prior phase, but the methodology persisted. As interest in art investment picked up again, it was statistician Jeremy Eckstein who was tapped to put together a renewed art market index, the Sotheby Index. This was even more aligned with financial investment motives, with publication in financial newspapers including Barron's and Fortune. The Sotheby Index

\footnotetext{
${ }^{5}$ The primary examples would be hedonic regressions and repeat-sales regressions, which are often-used methods to construct price indices for infrequently traded assets like real estate or art.
} 
appeared in tabular form, and as we can see, it included a number of different categories of art and collectibles, although does not reference stocks and bonds in this particular instance.

Figure 3. The Sotheby Index (Barron's, 1982)

\begin{tabular}{|c|c|c|c|c|}
\hline \multicolumn{5}{|c|}{ The Sotheby Index } \\
\hline $\begin{array}{l}\text { Cotezon } \\
\text { Old Master Paintings } \\
\text { 19th Century European Paintings } \\
\text { Impressionist \& Post-1mpressionist Paintings } \\
\text { Modern Paintings (1900-1950) } \\
\text { American Paintings (1800-pre-WW II) } \\
\text { Continental Ceramics } \\
\text { Chinese Ceramics } \\
\text { English Silver } \\
\text { Continental Silver } \\
\text { American Furniture } \\
\text { French \& Continental Furniture } \\
\text { English Furniture }\end{array}$ & $\begin{array}{l}\text { in } \\
1218 \\
201 \\
179 \\
248 \\
249 \\
450 \\
293 \\
445 \\
175 \\
140 \\
209 \\
228 \\
279\end{array}$ & $\begin{array}{l}\text { jun } \\
\text { 3th } \\
201 \\
179 \\
248 \\
249 \\
450 \\
293 \\
445 \\
175 \\
140 \\
209 \\
228 \\
279\end{array}$ & $\begin{array}{l}5 x p \\
199 \\
199 \\
176 \\
239 \\
232 \\
424 \\
299 \\
459 \\
160 \\
143 \\
209 \\
218 \\
270\end{array}$ & $\begin{array}{l}\text { Sop } \\
1950 \\
255 \\
225 \\
206 \\
204 \\
350 \\
336 \\
462 \\
205 \\
179 \\
172 \\
232 \\
256\end{array}$ \\
\hline $\begin{array}{l}\text { Weighted aggregate } \\
\qquad 1982 \text { Sotheby Parke Bernet Inc. } 1975=100 .\end{array}$ & 249 & 249 & 244 & 253 \\
\hline
\end{tabular}

Art price services. Building on earlier ways of providing art market information, such as the popular annual guides to auction prices, a number of entrepreneurs realized that there was a widespread demand for price and other information about art from both investors and collectors. Pension funds were later joined by the museum community, due to the public accounting rules that required public museums to capitalize, or report estimated dollar values for their collections in New Zealand and Australia (Carnegie \& Wolnizer, 1996).

The story of Artnet's development is informative. Amy King, former Vice President of the Artnet Price Database, noted that the company was founded due to the frustration the founders had with the existing art price information. In 1989, Pierre Sernet partnered with Hans Neuendorf and three others to found a company called Centrox, which tried to meet some of the information needs for the opaque art market. Their key innovation was to upstage the art price books through the introduction of a subscription-based fax service. This allowed the company to provide frequent price updates for subscribers, and with the development of the internet, this service evolved into one that was hosted online. By the early 1990s they provided online imaging and full cataloging, and in 1995, Artnet.com was founded (King 
interview, 2009). In interviews, Neuendorf has explicitly mentioned the desire to recreate structures and institutions that were present in other types of markets, "I mean, why should perfectly normal standard rules and use of information in any market - be it real estate or be it the stock exchange or be it manufacturing - why should that not apply for the art market?»6

\subsection{Funds and Ventures}

Art Banking Services. One new development in this stage was the growth of art banking and financial services. For example, Sotheby’s opened its financial services unit in 1988 (Horowitz, 2011). These services were presented as an attraction for the high net worth clients in the private banking space, but the idea of coming to one's bank to get art collection advice indicates the mixing of monetary, aesthetic and other motives.

Dedicated Art Funds. As opposed to the efforts of the earlier institutional investors, like the well-funded British Rail Pension Fund, we see additional options for how to invest in art. These were the dedicated art investment funds, with a portfolio that was comprised entirely of works of art, and these were typically organized using some kind of hedge fund structure. For example, in the 1980s, Chase Manhattan Bank attempted to collect \$300 million in investments from pension funds for a closed-end art fund, but failed to gain the necessary capital (Horowitz, 2011). The idea was that dedicated funds would be a way for investors to gain exposure to the art market, but without needing to have detailed knowledge and expertise. Funds like this were conceived in a time where alternative investments were growing in popularity. Despite these advantages, as the art market slid downwards in the early 1990s, the popularity of such ventures decreased.

\footnotetext{
${ }^{6}$ Quote from Vernissage.tv (2006). http://www.artfacts.net/index.php/pageType/newsInfo/newsID/3304/lang/1
} 


\subsection{Failures}

Cancellation of the Sotheby Index. The Sotheby Index was cancelled in the 1990s. This was again a period when the art market was declining. According to Eckstein, reasons for the discontinuation of the index included the fact that many people inside Sotheby's felt that the auction house could not be associated with a declining index, that people were becoming more aware of conflicts of interest (i.e., an auction house creating its own index), and the creators of the index started to have concerns about its validity and representativeness (Eckstein interview, 2009).

\section{Stage 4: Formalization and Professional Services (1990s to present)}

Changing Perceptions. Coming into the present, we see a greater acceptance of art as an investment. Although mainly a niche investment, today art is listed in investment industry publications like the CapGemini World Wealth Report (e.g. 2008, 2010), where it is categorized as a type of “passion investment.” In a survey at the London Art Fair in 2009, $71 \%$ of respondents said that art was or could be a type of investment, though many qualified their response, saying that investment value was only part of the attraction (2011a). In a survey that included 19 private banks, 140 international art professionals and 48 international collectors, Deloitte and ArtTactic found that over half of the art advisors and collectors who responded saw art as an asset class (Deloitte \& ArtTactic, 2011). When contrasted with the earlier British Rail Pension Fund example, we can see a greater acceptance.

\subsection{Explosion in Art Price Information and Market Research}

Current Academic Research on Art as an Investment. The increased availability of art price data and the advancements in computing power allowed a new wave of academic literature to emerge around the turn of the century, beginning with Mei and Moses (2002). Based on a new dataset of repeat sales (resales) of painting at Sotheby's and Christie’s, they constructed 
a price index for the period 1875-2000. The authors reported returns that compared favorably to those of bonds while covarying little with equities, meaning that paintings do not tend to overlap the market swings of stocks. The authors therefore concluded that art may play a more important role in portfolio diversification than found in previous studies. The findings of Mei and Moses, who have commercialized their indices, have been frequently quoted by journalists- and by art market players: their website claim that over 500 articles have used the indices. In line with their results, Campbell (2008) used estimates of the returns of art from both Art Market Research and Mei and Moses to examine optimal portfolio allocations, and came to the conclusion that "art's low correlation with other asset classes offers diversification benefits from holding art in an investment portfolio.” However, based on a database of over one million transactions from an online art price service, Renneboog and Spaenjers (2012 forthcoming) recently pointed out that the returns realized at the top auction houses may not be representative for the overall art market, while Hiraki et al. (2009) and Goetzmann et al. (2011) reported that art prices covary substantially with equity returns and with top incomes.

It is therefore still an open issue under which conditions art can be useful as a portfolio diversifier. Answering this question is further complicated by the relatively high transaction costs in this market, by the difficulty (or undesirability) of holding a diversified art portfolio, and by the potential sensitivity of art prices to changes in art market sentiment (Renneboog \& Spaenjers, 2012 forthcoming). Moreover, a shared limitation of the above-mentioned papers and other studies that focus on specific categories of art (see, for example, Worthington and Higgs (2006) on modern and contemporary Australian art, Pesando and Shum (2008) on modern prints, Kraeussl and Logher (2010) on art from emerging markets, etc.) is that they are not able to shed light on the profitability of the types of arbitrage opportunities that art investors often target and claim to exploit, which are likely to be idiosyncratic and not 
systematically reported. Finally, from a financial-economic theory perspective, a fundamental challenge is to determine the expected return on art: because of the pleasure it gives to owners, buyers may overpay relative to the investment component, and we do not necessarily know the risk profiles, meaning that it is difficult to calculate an expected value. So far, little research on this topic exists, with Mandel (2009) being a notable exception.

Computer Technology and Developments in Price Visualization. A key innovation by some of the art price services was to change the way that these data were used and interpreted, providing foundations that enhanced the use of subsequent data. This trend was greatly facilitated by improvements in computing technology that allowed increasingly sophisticated analysis, access to large sets of data, and the internet revolution that allowed access to remote users and information. While using a record of sales prices in art to look at trends and changes is not a new phenomenon, as mentioned before, it was enhanced by new technology.

New Buyers. The development of internet technology is thus an important component in terms of price provision, but it also coincided with the entry of new types of art buyers, because “... new buyers have been entering the market and they need information more quickly and that helps explain things like Artnet” (art price service interview 2007). New buyers wanted information in new ways, and were not content to examine books of prices. This entry of new buyers also helps to drive the related growth of art market analyst services. Art Market Analysts. As the art financialization project progress, entrepreneurs realized they could provide services in this uncrowded market, and a key example was that of advisories and other professional services. These include Seymours, providing advice, valuation and research services, and Fine Art Wealth Management, a firm that provides information needed by large investors who want to exercise due diligence in this market, as well as best practices for art funds and investment. ArtTactic, an art market research firm, is another example, offering bespoke research and art market sentiment indexes. 
Growing Capabilities of Art Price Services. The existing art price providers have also consolidated and expanded. Today these services provide aggregated price data from auction sales in various forms, along with additional art market information, via online subscription services. Some of these companies have grown into publically listed firms; at the start of 2013, Artprice is listed on the Euronext with a market capitalization of about $€ 200$ million. This growth in the art price information services indicates the sustained development of professional services around this industry, helping to support an ecology of information and knowledge about the art market.

\subsection{New Organizational Structures for Art Investment: Private Equity}

Sotheby’s lecturer Jeremy Eckstein has noted that "the issue is no longer whether or not art is a viable, attractive asset class, that can now be taken as a given. The only substantive issue now is the most effective means of structuring efficient vehicles for investing in art” (2008: 74). Eckstein's point about the way to structure investment vehicles in this area underscores another evolving, and important form of knowledge about art as an investment. This more practical knowledge about how best to structure the investment and to profit from it is still developing, and the experimentation with different investment vehicles explains the organizational evolution from investors directly purchasing artwork, to forming public, exchange-listed ventures, to the latest organizational structure, namely a format that is similar to that of longer-term private equity funds. Fernwood investments and the Fine Art Fund opened in 2003 and 2002, respectively. Daniella Luxemborg opened ArtVest investments in 2004, and plans were made for the Art Collectors Fund and the Art Dealers Fund. According to some sources, in the first half of 2005, there were plans to launch at least six investment funds, with another half-dozen expected to go public.

The significance of this investment structure is that it provides a convenient "container” for the artwork. As opposed to earlier ventures, where individuals and firms were investing 
directly in artwork, shares in a private equity fund are more fungible. They can be compared against other types of private equity investments at the due diligence stage, they feature a fund manager who can be examined for her or his track record, and they are able to trade in a relatively opaque fashion that (in theory) would help to avoid issues of speculation and market bubbles caused by rapid trading. As with venture capital, in the unregulated art market, such funds may also help to "develop" assets in a more hands-on fashion, in contrast to the insider trading concerns that would be present for the stocks of publicly held companies.

\subsection{Further Developments}

In addition to art price services, analysts and new organizational forms, we also see a number of developments in what could be called the ecology of the industry.

Education Programs. If one of the key findings about this industry is the development of new knowledge about the art market and art investing, one of the major ways in which this knowledge has been diffused has been the creation of education programs. Started as a diversification strategy, Christie’s and Sotheby’s auction houses now both have education programs, offering professional master's degrees and certificate programs in various cities. In 2007, Euromoney training offered a course entitled "Investing in Art: A New Alternative Asset Class," a 3 day course "specifically developed for investors and their clients who are looking to include Art as an asset in their investment portfolios.”7

Art Loans and Finance. Another development has been the addition of different types of financial services related to art. For example, the firm Fine Art Capital was available to lend “to individuals, art dealers, trusts \& estates, and museums seeking to finance new acquisitions and borrow against an existing collection of art and antiques.”8 Art Finance Partners, based in

\footnotetext{
${ }^{7}$ Euromoney Training Flyer, “Investing in Art: A New Alternative Asset Class,” 1/24/2007. Sourced 5/1/2007 from www.euromoneytraining.com/uk

${ }^{8}$ http://www.fineartcapital.com/hp_v5_aboutus1.html. Sourced 4/9/2007
} 
New York, provides “fast, flexible and innovative credit solutions to the owners of unconventional assets..."9 Actors in this area also make explicit the view that they consider art to be a financial asset. Ian Peck of New York’s Art Capital Group noted in 2006 that “private banking clients’ assets in the world are about $\$ 7$ trillion. The banks estimate that about 15 per cent of those assets are comprised of artworks. That means there's about a trillion dollars worth of art that can be leant against” (quoted in Dizard, 2006).

\subsection{Failures and the Problem of Speeding the Market}

Even in this last stage there have been failures, and only time will tell whether these mark a new stage of activity or a continuation of a growth phase that was punctuated by the global financial crisis. So the various failures that follow should be considered in context with the financial crisis. However, the relationship is also somewhat unclear. The financial crisis began with a credit crunch that dried up liquidity (Murphy, 2009), which naturally reduced the flow of money into new ventures. On the other hand, with the consideration that hard assets like art hold money through a crisis, it is also possible that some ventures benefitted from the economic uncertainty.

Art Fund Failures. Failures swept through the art fund sector and included a number of ventures, with some funds closing and others falling back to more modest goals. Failures prior to the financial crisis were explained in different ways by insiders. "Most funds just don't have the kind of track record necessary to get institutional investors. There are a lot of "friends and family funds" which is basically like a line of capital with one art dealer at the helm. But they can't get the institutional investors because they have too many conflicts of interest” (art fund interview 2007). Many of the art funds opened by firms without significant expertise in artwork failed because they were unable to attain sufficient investment capital,

\footnotetext{
${ }^{9}$ http://www.artfinancepartners.com/services.php. Sourced 1/2/2013
} 
according to one art fund representative (interview 2007). Other problems occured when financial professionals try to start a fund without sufficient knowledge and connection to the art market, which is problematic because the art market still requires such a degree of insider knowledge. Another notable problem was the failure of a proposed fund of funds, a second level of diversification effort that was put together by ABN-AMRO. According to one interviewee, in the case of the fund of funds, there were too few up-and-running funds available for this to happen (art fund interview 2007). It was thus no surprise when ABNAMRO closed the effort only two years after it had launched (Adam \& Mason, 2005). More recent failures may have had a stronger impact from the financial crisis. Osian Art launched a three-year closed end fund in 2006, which faced difficulties in 2009 when the works held were not selling; according to the chief advisor: “...the art would not sell at any price...” (quoted in MoneyLife Digital Team, 2011).

Market Transparency and Inefficiency. Randall Willette of Fine Art Wealth Management mentioned the continuing lack of transparency in the art market, noting that it is exploited by investors such the art funds, but is still seen to be problematic by some investors. "Yes. It's also been historically one of the criticisms of the art market," that is has been "very much of an insider's market,” dominated by a small group of market insiders. Although the internet has added transparency to the market, there are "still a lot of inefficiencies that exist," including illiquidity, emotionally driven decision making, and lack of pricing standardization. In addition, there is no "universally ... accepted index as of yet” (Willette interview 2009). Failures in Models and Tools: Art Market Research’s Bloomberg Adventures. Failures can also be seen in the area of models and tools. Interestingly, around 2007, Art Market Research had partnered with Bloomberg to allow financial analysts to access price data using their native platform via the Bloomberg terminal, providing more than 20 indices for different art and collectible sectors. This not only allowed financial analysts and investors to examine the 
art price data in their normal trading interface, but also allowed users to plot desired comparisons with other types of investments on the chart. It enabled correlations, trend analysis and other types of quantitative research using the Bloomberg analysis tools. But this push forward was perhaps too sudden, and the Bloomberg listings were cancelled.

Despite these failures, we can see that as the tools and knowledge about artwork were developed, and the successes of efforts like the Fine Art Fund were promoted, we see a growing acceptance of artwork as a legitimate investment area. There are continuing questions, but fewer calls that art is never an acceptable investment area. Moreover, there has been a flourishing in the professional service offerings.

\section{Emergent Themes}

Supporting Infrastructure and Information. One way to explain the growing understanding of art investment is to consider this to be a story of the development of the supporting infrastructure (Star, 1999), the analysts and professional services. These were organizational field-level changes, prompted through the growth of financial logics, which helped to prioritize the use of art price information and the development of supporting industries. There was a growth in information, available in higher quantity, quality, and at faster intervals. This growth of information and supporting services helps to enable new knowledge about the market and a set of more sophisticated tools. In addition to information providers (essentially spot prices), and benchmarks and measures that gave a general view of the art market (trend data), it was essential to add a type of practical knowledge about investment vehicle structure to take advantage of increased information about the investment properties of art.

Models and Tools: Dissemination of Knowledge about Art Investing. The growing number of models and tools is one of the emergent findings of study 2. This suggests a case of isomorphism, and indeed many of the developments are linked to similar existing or developing tools in other markets. This development helps to move the academic 
understanding back to a wider, more popular understanding, with the legitimacy that is conferred by these graphs. Visualization of price information is one type of innovation that helps to increase the knowledge of art investment, as well as to disseminate this knowledge, as seen in the spread of the Times-Sotheby Index charts in newspapers. The tools also allow direct comparisons between art and other investments, as seen in Rush's charts in Figure 2. Such tools were also a necessary component in enabling the various calculations needed by professional investors, which can be understood as a type of performativity effect (MacKenzie \& Millo, 2003). In this role, an index or chart serves the analytical function of displaying price trends, but also creates new knowledge about the processes under study, as a re-presentation (see also Coslor, 2011b).

Theoretical Justifications. In another point about institutional expectations, another important feature of this emerging industry, following from the work of Lounsbury and Crumley (2007), is that we should examine the role of the theoretical justifications of the development of the area. As with their study of the mutual fund industry, the theory of portfolio diversification provides an important set of theoretical justifications for looking at different types of investments.

Firm and Investment Structures. In addition to models and tools that helped to progress an understanding of the properties of art investment, we also see experimentation around different structures to organize the investment. We might apply Williamson’s transaction costs approach (1981) to explain the progress from general investors like the British Rail Pension Fund owning art directly, toward external securitization via the dedicated art investment funds. Certainly the direct ownership of art was more than a typical mutual fund wanted to deal with, although there was also a proliferation of different financial forms, such as the art exchanges seen in stage 4 . 
To sum up the historical case then, instead of being able to say that one of the above factors was at play, each one is a necessary but insufficient condition for the development of a sustained art investment industry. The following timeline tells a story of industry development and change.

Figure 4. Development of the Organizational Field

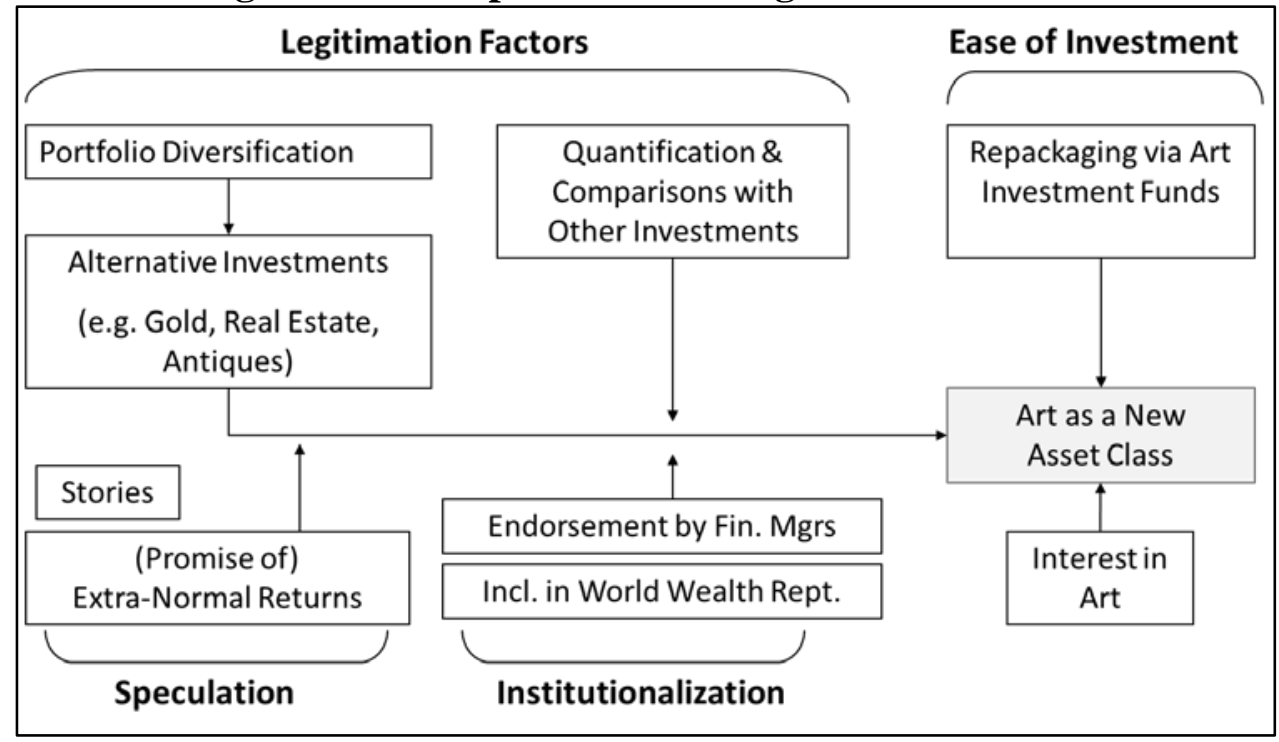

This complicated history indicates that entrepreneurs, price data, and investment vehicle knowledge are each necessary, but insufficient factors in explaining the growing, if still incomplete, legitimacy of art as an investment category. Over time, all of these factors had to come together to enable art investment to be seen as increasingly credible, and this historical study helps to unpack the process of learning about the investment properties of art via the growth of new models and tools, a process which runs concurrently with a process of experimenting with different investment vehicles and firm structures.

\section{GENERAL DISCUSSION}

At this point, it is unclear whether art has achieved a durable status as an asset category, or whether it will be subject to a new cycle of disenchantment, with the potential of renewed interest at a future point in time. While art has historically been considered as a type of investment, in that it can hold value over time or provide a monetary return upon resale, it has 
not been an easy area for rational and professional investment. Apart from the difficulties in assessing the financial properties of a given artwork, due to uniqueness, we also see sharply different institutional logics at work in the financial and the art market. What is clear, however, is that we can see a number of key components that have come together to support this industry, with research, professional services and investment structures. If we accept the proposition that art is generally considered to be an investment at the moment—albeit a complicated, niche investment with little chance of becoming mainstream-the question is how we might make sense of the various developments and failures from the two studies. Integrating the Studies. The lexical analysis shows an increasing attention to the art market and art investment, over and above the growing interest in paintings or art in general. For this reason, we can clearly identify a growing market interest over time, suggesting a sustained and growing interest in the art market and investments. This finding proves to be a foil to the findings of study 2, illustrating sustained potential interest, despite changing views about whether the specific operationalizations of investments or information tools were a good idea or not. Metaphorically, this sustained interest might be seen as the base for our entrepreneurs, a steady burn that can catch with the introduction of new firms and ideas.

In contrast with the relatively sustained growth in attention shown in study 1 , the structural and epistemic moves of study 2 were somewhat arbitrarily broken down into four stages with the goal of making the cyclical nature of the area more clear. These stages use somewhat arbitrary cut points for a more continuous and messy process. But it is possible to see a type of cycle, where each stage contains a flourishing of activity, including both new firms and new models, followed by upsets and die-offs. This iterative, cyclical growth model of organizational field development is helpful to show how knowledge accrues and even failures help to support further development of the area, rather than the failure of the concept. So in contrast to the idea that increased attention alone is responsible for the development of art 
investment, we argue that simultaneous and mutually supportive movements in terms of the development of the organizational field and constituent knowledge were fundamental to explaining the growing credibility of art as an investment.

\section{A Theory of Experiments and Failures over Time}

The discussion of the various stages and failures in this emergent industry and asset category lead us to develop a historical theory of category and industry emergence. Again, the epistemic cultures view provides a helpful way to understand that failures can still lead to progress. Just as an experiment in high-energy physics can fail because of misspecification, instead of thinking of the specific examples of art investment fund failures as a general failure of art as an asset, they could be looked at as experiments to develop a workable structure and concept.

The Expected Rate of Development

We presented a story of developing tools, structures and knowledge about art. But these developments were not always successful. As the financialization project progressed, developments such as a fund of funds in artwork were proposed, providing a service that is common to other investment categories. But this and certain other efforts proved to be premature, given the level of development in the market. There was not yet the necessary foundation for the development, and more detailed analysis of the fund of funds failure helps to display some general properties about the development of the field. As an art fund representative noted, "people are trying to speed the market, with things like art derivatives, like this fund of funds of ABN [AMRO], but that this was way too soon, possibly 20 years too soon to recommend this, because you want to have a bunch of funds and want to be able to make choices between them and need track records to do this” (art fund interview 2007). This example helps to illustrate two points. The first is that entrepreneurs can get ahead of 
themselves in such a project. There can be fits and starts to this activity, and without the requisite organizational support and development in the art investment area, reinterpreting typical practices from financial investment-in this case a fund of funds-is not possible in practice, even though the practice is well-established in other markets. The second thing that we can take away is that even industry insiders have a sort of mental model about what the natural progression of the industry looks like, and take it for granted that there will be some additional failures along the way, especially if actors and entrepreneurs are moving too quickly.

\section{Learning Curves and Natural Failure Rates}

According to Philip Hoffman of London’s Fine Art Fund, “there's a learning curve, just like (real-estate investment trusts) were 20 years ago... The first property fund had zero subscriptions, the fourth one was 200 percent oversubscribed” (quoted in Baram, 2005). In looking at the new art funds that opened between 1999 and 2003, only to face a wave of closures, we might picture the learning curve mentioned by Hoffman, with a higher rate of failures at the beginning of such a project, which would decline as knowledge about the area developed.

In addition, there is likely to be an underlying 'natural failure rate,' as in other industries. A few related examples may be helpful. Researchers of entrepreneurship and innovation speak of a 'natural failure rate' in different industries. For example, in the restaurant industry, an industry known to have a high failure rate, approximately one quarter of ventures fail in the first year (Parsa, Self, Njite, \& King, 2005). Failure rates can also vary over time. For example, mutual funds had a 10-20\% failure rate in the 1950s-1980s, but this rate spiked in the 1973-1974 bear market, and again in the 1990s, when it grew to 36\% (Bogle, 2005).

In this sense, failures are necessary, essential to the progress of the concept, because they help to test the limits or to develop new understandings, even if these are temporary. This 
relates both to the idea of a learning curve and to the natural failure rate. So instead of seeing failures as challenges to the concept, we should envision failures as the natural byproduct of the process of experimentation and learning by firms and individuals in a new field, a process that is also seen in the history of innovation-based companies (e.g. Powell \& Sandholtz, forthcoming).

\section{The Limits of the Market}

On the other hand, even if a learning curve and a certain rate of failures can be expected, that is not to say that we anticipate that art will become a mainstream investment. Art is something that has been known to hold value over time, but without any guarantees. Art is an illiquid, opaque asset that pays no dividends but comes with large storage, insurance, and transaction costs. So it is unlikely to become an easy or "normal" investment. There is also the concern that, as in other markets, excessive investment demands can create market bubbles. We have concerns about the impacts of "promotion” of art investment by art industry players such as funds and advisories - given that these actors are also selling products, to listen to their hopes that the market would become more attractive to investors, more professional, and more "financial" raises questions about whether these new customers will show a sustained interest or whether this is a temporary fad. At the very least, we should think about what that means for art price levels (and their sustainability) if investment or speculation dominates collectors.

\section{Epistemic Innovations vs. Durable Institutional Expectations}

Despite these important concerns, a theory of failures, while not new to studies of entrepreneurship, is helpful to show why the epistemic cultures view is a natural complement to institutional theory. It helps to provide context for fast-moving tests, trials and pushes toward an industry or concept, while interacting with the more durable institutional 
expectations. We believe, however, that the introduction of epistemic cultures provides a practical benefit for the study of changing institutions and practices, by allowing us to suggest that institutions generally have durable and long-range expectations, whereas in the epistemic cultures view, there is room for rapid changes, sketches, drafts, experiments and failures.

Although there is considerable research on changing institutional expectations and logics, this is actually a case of more durable institutionalized expectations from financial investment forming a barrier to the growth of what is now an established art investment market. This relates well to work about the development and use of measurement tools by entrepreneurs to gain power and legitimacy (e.g. Dejean, Gond, \& Leca, 2004), but instead of assuming institutional-level changes, the epistemic cultures model can explain industry developments in the face of durable institutions, as well as the ways that this knowledge can be provided by analyst or knowledge-providing firms as a new actor in the field.

\section{Conclusion}

This case helps to explain the puzzle of for how art could long be considered as a possible investment, but only quite recently become relatively accepted as a legitimate area by large investors, due to strong and durable institutionalized expectations about what constitutes a legitimate investment. (Which, again, is not to say that we believe that art is necessarily a good investment.) The sustained interest in the art market and art investment indicates the long duration of this as a potential investment category, with a history of efforts toward making it so. But despite the interest, it was difficult to operationalize into a seemingly legitimate investment. The case provides some interesting findings for the study of industries and financial instruments, highlighting the role of durable institutional expectations, the need for models and tools, and the long road that entrepreneurs and promoters will face when dealing with investment returns that are difficult to quantify. 


\section{References}

1973. Front Matter, The Burlington Magazine, Vol. 115: i-lxxxvi: The Burlington Magazine Publications, Ltd.

Adam, G. \& Mason, B. 2005. Art Funds Struggling, Forbes, Online ed. New York.

Anderson, R. C. 1974. Paintings as an Investment. Economic Inquiry, 12(1): 13-26.

Baram, M. 2005. 'Art Funds' Starved for Investors, The Wall Street Journal. New York.

Barclays \& Ledbury Research. 2012. Profit or Pleasure? Exploring the Motivations Behind Treasure Trends, Wealth Insights, Vol. 15: Barclays.

Barron's. 1982. The Sotheby Index: 62: Barron's National Business and Financial Weekly.

Baumol, W. 1986. Unnatural Value: Or Art Investment as Floating Crap Game. The American Economic Review, 76(2): 10-14.

Blake, D. 2003. Pension Schemes and Pension Funds in the United Kingdom. Oxford: Oxford University Press.

Bogle, J. C. 2005. The Mutual Fund Industry 60 Years Later: For Better or Worse? Financial Analysts Journal, January/February: 30-39.

Bryan, M. F. 1985. Beauty and the Bulls: The Investment Characteristics of Paintings. Economic Review, 21(1): 2-11.

Callon, M. 1987. Society in the Making: The Study of Technology as a Tool for Sociological Analysis. In W. E. Bijker \& T. P. Hughes \& T. Pinch (Eds.), The Social Construction of Technological Systems: New directions in the sociology and history of technology: 83-103. Cambridge MA: MIT Press.

Campbell, R. A. 2008. Art as a Financial Investment. Journal of Alternative Investments, 10(4): 64-81.

Cannon-Brookes, P. 1996. Art Investment and the British Rail Pension Fund. Museum Management and Curatorship, 15(4): 406-407.

Capgemini \& Merrill-Lynch. 2008. The World Wealth Report, Vol. 12th Annual Report. New York: Capgemini and Merrill-Lynch.

CapGemini \& Merrill-Lynch. 2010. The World Wealth Report, Vol. 14th Annual Report. New York: Capgemini and Merrill-Lynch.

Carnegie, G. D. \& Wolnizer, P. W. 1996. Enabling Accountability in Museums. Museum Management and Curatorship, 15(4): 371-386.

Carruthers, B. G. \& Stinchcombe, A. L. 1999. The social structure of liquidity: Flexibility, markets, and states. Theory and Society, 28(3): 353-382. 
Chamaz, K. \& Mitchell, R. 2002. Grounded Theory in Ethnography. In P. Atkinson (Ed.), Handbook of Ethnography. London: Sage.

Coffman, R. B. 1991. Art Investment and Asymmetrical Information. Journal of Cultural Economics, 15(2): 83-94.

Coslor, E. 2011a. Wall Streeting Art: The Construction of Artwork as an Alternative Investment and the Strange Rules of the Art Market. Unpublished Doctoral Thesis, University of Chicago, Chicago.

Coslor, E. 2011b. A Pound of Sugar is a Pound of Sugar: Measuring and Quantifying the Art Market, Investment and Analysis from the 1960s to 1990s, American Sociological Association Conference. Las Vegas, NV.

Dejean, F., Gond, J.-P., \& Leca, B. 2004. Measuring the Unmeasured: An Institutional Entrepreneur Strategy in an Emerging Industry. Human Relations, 57(6): 741-764.

Deloitte \& ArtTactic. 2011. Art and Finance Report 2011. Luxembourg: Deloitte Luxembourg and ArtTactic.

DiMaggio, P. J. 1988. Interest and agency in institutional theory. In L. G. Zucker (Ed.), Institutional Patterns and Organizations: 3-22. Cambridge, MA: Ballinger.

Dimson, E. \& Spaenjers, C. 2011. Ex post: The investment performance of collectible stamps. Journal of Financial Economics, 100: 443-458.

Dizard, J. 2006. A picture of healthy growth, The Financial Times, Online ed.

Duthy, R. 1978. Alternative Investment: A guide to opportunity in the collectibles market: Joseph.

Duthy, R. 1986. The Successful Investor: A Guide to Art, Gold, Wine, Antiques and Other Growth Markets: HarperCollins.

Eckstein, J. 2008. Investing in Art: Art as an Asset Class. In I. Robertson \& D. Chong (Eds.), The Art Business: 69-81. London: Routledge.

Eisenhardt, K. M. 1989. Building Theories from Case Study Research. The Academy of Management Review, 14(4): 532-550.

Eisenhardt, K. M. \& Graebner, M. E. 2007. Theory Building from Cases: Opportunities and Challenges. Academy of Management Journal, 50(1): 25-32.

Frey, B. \& Pommerehne, W. 1989. Art Investment: An Empirical Inquiry. Southern Economic Journal, 56(2): 396-409.

Frey, B. S. \& Eichenberger, R. 1995. On the rate of return in the art market: Survey and evaluation. European Economic Review, 39(3-4): 528-537.

Friedland, R. \& Alford, R. R. 1991. Bringing Society Back In: Symbols, Practices, and Institutional Contradictions. In W. W. Powell \& P. J. DiMaggio (Eds.), The New 
Institutionalism in Organizational Analysis: 232-263. Chicago, IL: University of Chicago Press.

Glaser, B. G. \& Strauss, A. L. 1965. Discovery of Grounded Theory: A Basic Strategy Underlying Qualitative Research. American Behavioral Scientist, 8(6): 5-12.

Glaser, B. G. \& Strauss, A. L. 1967. The Discovery of Grounded Theory: Strategies for Qualitative Research. Chicago: Aldine Publishing Company.

Goetzmann, W. 1993. Accounting for Taste: Art and the Financial Markets Over Three Centuries. The American Economic Review, 83(5): 1370-1376.

Goetzmann, W. N., Renneboog, L., \& Spaenjers, C. 2011. Art and Money. American Economic Review, 101(3): 222-226.

Google; Google Books Ngram Viewer; http://books.google.com/ngrams/datasets; 9/26/12.

Hayden-Guest, A. 1996. True Colors: The Real Life of the Art World. New York: Atlantic Monthly Press.

Hensher, P. 2006. When even the most monstrous works of art cost millions, it's time for a price crash, The Guardian, Print ed.: 23. London.

Hiraki, T., Ito, A., Spieth, D. A., \& Takezawa, N. 2009. How Did Japanese Investments Influence International Art Prices? Journal of Financial \& Quantitative Analysis, 44(6): 1489-1514.

Horowitz, N. 2011. Art of the Deal: Contemporary Art in a Global Financial Market. Princeton NJ: Princeton University Press.

Knorr Cetina, K. 1999. Epistemic Cultures: How the Sciences Make Knowledge. Cambridge: Harvard University Press.

Kraeussl, R. \& Logher, R. 2010. Emerging art markets. Emerging Markets Review, 11(4): 301-318.

Lake, K. R. 1970. Stamps for Investment. London: W.H. Allen.

Lounsbury, M. \& Crumley, E. T. 2007. New Practice Creation: An Institutional Perspective on Innovation. Organization Studies, 28(7): 993-1012.

MacKenzie, D. \& Millo, Y. 2003. Constructing Markets, Performing Theory: The Historical Sociology of a Financial Derivatives Exchange. American Journal of Sociology, 109(1): 107-145.

MacKenzie, D. 2011. The Credit Crisis as a Problem in the Sociology of Knowledge. American Journal of Sociology, 116(6): 1778-1841.

Mandel, B. R. 2009. Art as an Investment and Conspicuous Consumption Good. American Economic Review, 99(4): 1653-1663. 
Marcus, G. 1995. Ethnography in/of the World System: The Emergence of Multi-Sited Ethnography. In G. Marcus (Ed.), Ethnography Through Thick and Thin: 79-104. Princeton: Princeton University Press.

Markowitz, H. 1952. Portfolio Selection. Journal of Finance, 7(1): 77-91.

McAndrew, C. 2012. The International Art Market in 2011: Observations on the Art Trade over 25 Years. Maastricht, Netherlands: TEFAF.

Mei, J. \& Moses, M. 2002. Art as an Investment and the Underperformance of Masterpieces. American Economic Review, 92(5): 1656-1668.

Michel, J.-B., Shen, Y. K., Aiden, A. P., Veres, A., Gray, M. K., Team, T. G. B., Pickett, J. P., Hoiberg, D., Clancy, D., Norvig, P., Orwant, J., Pinker, S., Nowak, M. A., \& Aiden, E. L. 2011. Quantitative Analysis of Culture Using Millions of Digitized Books. Science, 331(6014): 176-182.

MoneyLife Digital Team. 2011. Osian Art Fund failure: Mr Tuli’s version, MoneyLife, Online ed.

Munesia, F., Millo, Y., \& Callon, M. 2007. An Introduction to Market Devices. The Sociological Review, 55(s2): 1-12.

Murphy, D. 2009. Unravelling the Credit Crunch. Boca Raton, FL: Chapman \& Hall / CRC. Parsa, H. G., Self, J. T., Njite, D., \& King, T. 2005. Why Restaurants Fail. Cornell Hotel and Restaurant Administration Quarterly(August): 304-322.

Pesando, J. 1993. Art as an Investment: The Market for Modern Prints. American Economic Review, 83(5): 1075-1089.

Pesando, J. E. \& Shum, P. M. 2008. The Auction Market for Modern Prints: Confirmations, Contradictions, and New Puzzles. Economic Inquiry, 46(2): 149-159.

Powell, W. W. \& Sandholtz, K. forthcoming. Chance, Necessité, et Naïveté: Ingredients to create a new organizational form. In J. Padgett \& W. W. Powell (Eds.), The Emergence of Organizations and Markets. Princeton NJ: Princeton University Pres.

Reitlinger, G. 1961. The Economics of Taste; v. 1: The Rise and Fall of the Picture Market, 1760-1960. London: Barrie and Rockliff.

Reitlinger, G. 1963. The Economics of Taste; v. 2: The rise and fall of the objets d'art market. London: Barrie and Rockliff.

Reitlinger, G. 1970. The Economics of Taste; v. 3: The Art Market in the 1960s. London: Barrie and Rockliff.

Renneboog, L. \& Spaenjers, C. 2012 forthcoming. Buying Beauty: On Prices and Returns in the Art Market. Management Science.

Rheims, M. 1959. La vie étrange des objets: histoire de la curiosité. Paris: Plon. 
Rheims, M. 1961. Art on the Market: Thirty-Five Centuries of Collecting and Collectors from Midas to Paul Getty (D. Pryce-Jones, Trans.). London: Weidenfeld and Nicolson.

Richards, L. 2005. Handling Qualitative Data: A Practical Guide. London: Sage.

Rush, R. 1961. Art as an Investment. Englewood Cliffs, NJ: Prentice-Hall.

Scott, D. L. 2003. Wall Street Words: An A to Z Guide to Investment Terms for Today's Investor. New York: Houghton Mifflin Company.

Star, S. L. \& Griesemer, J. R. 1989. Institutional Ecology, 'Translations' and Boundary Objects: Amateurs and Professionals in Berkeley's Museum of Vertebrate Zoology, 1907-39. Social Studies of Science, 19(3): 387-420.

Star, S. L. 1999. The Ethnography of Infrastructure. American Behavioral Scientist, 43(3): 377-391.

Stein, J. P. 1973. The Appreciation of Paintings. Unpublished Unpublished Doctoral Dissertation, University of Chicago, Chicago.

Thornton, P. H. \& Ocasio, W. 2008. Institutional Logics. In K. Sahlin-Andersson \& R. Greenwood \& C. Oliver \& R. Suddaby (Eds.), The SAGE Handbook of Organizational Institutionalism: 99-129. London, UK: Sage Publications, Ltd.

Tolbert, P. S. \& Zucker, L. G. 1983. Institutional sources of change in the formal structure of organizations: The diffusion of civil service reform, 1880-1395. Administrative Science Quarterly, 28: 22-39.

Velthuis, O. \& Coslor, E. 2012. The Financialization of Art. In K. Knorr Cetina \& A. Preda (Eds.), The Oxford Handbook of the Sociology of Finance: 471-487. Oxford UK: Oxford University Press.

Watson, P. 1992. From Manet to Manhattan: The Rise of the Modern Art Market. New York: Random House.

Williamson, O. E. 1981. The Economics of Organization: The Transaction Cost Approach. American Journal of Sociology, 87(3): 548.

Worthington, A. \& Higgs, H. 2006. A Note on Financial Risk, Return and Asset Pricing in Australian Modern and Contemporary Art. Journal of Cultural Economics, 30: 73-84.

Zuckerman, E. 1999. The Categorical Imperative: Securities Analysts and the Illegitimacy Discount. American Journal of Sociology, 104(5): 1398-1438. 